\title{
ANALISIS PENGARUH PEMBERIAN BANSOS COVID-19 TERHADAP MASYARAKAT DENGAN MENGGUNAKAN METODE RANK ORDER CENTROID (ROC).
}

\author{
ANALYSIS OF THE INFLUENCE OF THE PROVISION OF COVID-19 BANSOS ON THE \\ COMMUNITY USING THE RANK ORDER CENTROID (ROC) METHOD.
}

\author{
Agung Setiaman Hulu ${ }^{1}$, Muhardi Saputra ${ }^{2}$, Jhonly Marihot Hasudungan Sinambela ${ }^{3}$, \\ Siti Aisyah ${ }^{4}$, Palma Juanta ${ }^{5}$ \\ ${ }_{1,2,3,4}$ Universitas Prima Indonesia \\ 1,2,3,4 Sistem Informatika, Fakultas Teknologi dan Ilmu Komputer \\ Email :1'huluagung@gmail.com, ${ }^{2}$ muhardisaputra@unprimdn.ac.id, \\ [3]jhonlysinambela@gmail.com, ${ }^{4}$ siti_aisyah@unprimdn.ac.id, ${ }^{5}$ palmajuanta@unprimdn.ac.id
}

\begin{abstract}
Abstrak
Bantuan Sosial pada masa pendemi covid-19 merupakan program yang diimplementasikan oleh pemerintah Republik Indonesia dalam rangka membantu perekonomian Rakyat Indonesia dalam penghadapi situasi pendemi covid-19. Semua masyarakat di seluruh wilayah Indonesia yang mempunyai kriteria akan mendapatkan bantuan sosial ini. Salah satu wilayah yang diberikan bantuan sosial yaitu Desa Ujung Sedang, Kecamatan Tanjung Morawa, Kabupaten Deli Serdang. Kriteria yang digunakan pada penelitian ini adalah Keterangan Domisili, Pendapatan, Pekerjaan, Status Tempat Tinggal, Jumlah Anak, Kendaraan Bermotor dan Status Perkawinan. Jumlah penduduk yang banyak dengan berbagai ragam kriteria yang dimiliki setiap warganya membuat pihak petugas pemerintah kewalahan dalam mendata siapa saja waga yang benar-benar layak mendapatkan bantuan sosial tersebut. Metode ROC (Rank Order Centroid) dipilih peneliti untuk menganalisis kriteria sehigga didapat penentuan warga yang layak mendapat bansos. Hasil yang didapat pada penelitian ini adalah Warga B dan E mendapat skor yang tinggi sehingga menjadi calon penerima bantuan sosial yang layak. Diharapkan dengan adanya penelitian ini, maka akan meninimalisir kecemburuan social tentang siapa yang layak mendapatkan bantuan sosial dari pemeritah di masa pandemic covid-19.
\end{abstract}

Kata kunci: Rank Order Centroid (ROC), Metode, Bansos, kriteria, Masyarakat.

\section{Abstract}

Social Assistance during the COVID-19 pandemic is a program implemented by the government of the Republic of Indonesia in order to help the Indonesian people's economy in dealing with the COVID-19 pandemic situation. All communities throughout Indonesia who meet the criteria will receive this social assistance. One of the areas that was given social assistance was Ujung Medium Village, Tanjung Morawa District, Deli Serdang Regency. The criteria used in this study are information on domicile, income, occupation, residence status, number of children, motorized vehicles and marital status. The large number of residents with a variety of criteria owned by each of its citizens makes it difficult for government officials to list who is truly deserving of the social assistance. The ROC (Rank Order Centroid) method was chosen by the researchers to analyze the criteria so that the determination of residents who deserved social assistance was obtained. The results obtained in this study are Citizens $B$ and $E$ get high scores so that they become eligible candidates for social 
assistance. It is hoped that this research will minimize social jealousy about who deserves social assistance from the government during the COVID-19 pandemic.

Keyword: Rank Order Centroid (ROC), Method, Social Assintance, Criteria, Residents.

\section{PENDAHULUAN}

Bansos atau yang sering disebut dengan Bantuan Sosial yang di berikan Pemerintah kepada masyarakat yang kurang mampu, demi membantu dan meningkatkan kesejahteraan masyarakat kurang mampu akibat dari pandemi covid-19. Bansos ini merupakan program pemerintah dimana bantuan yang akan di berikan langsung kepada masyarakat kurang mampu sehingga membantu masyarakat untuk memenuhi biaya hidupnya.

Pemberian Bansos ini mempunyai dampak yang positif maupun dampak negatif. Salah satu dampak positifnya adalah meringankan beban masyarakat yang kurang mampu terlebih dalam memenuhi kebutuhan pokok. Dan dampak negatifnya dapat membuat masyarakat malas bekerja dan berusaha di karenakan mengharapkan Bansos perbulannya. Bansos sendiri diberikan kepada masyarakat yang memenuhi beberapa kriteria . Penelitian yang akan dilakukan yaitu dengan membuat sistem komputerisasi untuk menentukan penerima Bansos tersebut menggunakan metode Rank Order Centroid (ROC). Dimana ROC itu adalah merupakan satu dari beberapa metode pembobotan yang cukup sederhana ${ }^{[1]}$.

Sistem Penentuan pemberian bansos berbasis WEB untuk mempermudah dan transparan sehingga mudah diakses oleh masyarakat luas. Data masyarakat miskin yang akan diambil dari pemerintah menjadi hal yang penting sebagai masukan sistem ini. Pemerintah sudah mempunyai kriteria - kriteria siapa saja yang mendapatkan bansos, kriteria tersebut akan menjadi Profile kriteria yang nantinya akan dicocokan pada masyarakat penerima bansos.

Dalam prosesnya di masyarakat pemberian bansos tersebut ada beberapa permasalahan dalam proses pemilihan calon penerima bantuan seperti: Beberapa kategori masyarakat kurang mampu masih belum terlalu jelas, Masih kurangnya wawasan masyarakat akan mekanisme pemilihan calon penerima bantuan. Banyaknya masyarakat yang menerima bansos yang tidak produktif .

Menurut penelitian yang dilakukan oleh Mesran, dkk (2019), dalam penilaian kinerja dosen komputer dengan menggunakan metode Rank Order Centroid (ROC) dan Operational Competitiveness Rating Analysis (OCRA). Dengan adanya penetapan bobot dengan menggunakan metode Rank Order Centroid (ROC) dinilai memberikan kemudahan atas dasar pemberian bobot ${ }^{[2]}$.

Menurut penelitian yang dilakukan oleh Resi Tri Utami, dkk (2016) Sistem Pendukung Keputusan Seleksi pengguna jasa leasing mobil dengan metode Simple Additive Weighting (SAW) dan Rank Order Centroid (ROC). Dengan adanya penelitian ini dapat membantu pengambilan keputusan jasa sewa leasing mobil ${ }^{[3]}$.

Menurut penelitian yang dilakukan oleh Mesran, dkk (2019) efektifitas penilain kerja karyawan dalam peningkatan motivasi kerja dengan menggunakan metode Rank Order Centroid (ROC) dan Additive Ratio Assessment (ARAS). Dengan adanya penelitian ini dapat memberikan hasil yang efektif terhadap informasi yang diperoleh bagi manajemen ${ }^{[4]}$.

Berdasarkan uraian diatas, maka penulis melakukan penelitian dengan judul "Analisis Pengaruh Pemberian Bansos Covid-19 Terhadap Masyarakat Dengan Menggunakan Metode Rank Order Centroid (ROC)".

\section{METODE PENELITIAN}

Pada penelitian ini, peneliti menggunakan metode waterfall. Metode waterfall adalah metode yang digunakan dalam industri perangkat lunak. Metode waterfall memiliki tahapan-tahapan sebagai berikut: 
1. Analisis kebutuhan

Layanan sistem, kendala dan tujuan ditetapkannya oleh hasil konsultasi dengan pengguna yang kemudian didefenisikan secara rinci.

2. Desain

Tahapan perancangan sistem yang mengalokasikan kebutuhan sistem, baik perangkat keras maupun perangkat lunak.

3. Penulisan kode

Pada tahap ini, perancangan perangkat lunak direalisasikan sebagai serangkaian program atau unit program.

4. Pengujian

Unit-unit individu program atau program digabung dan di uji sebagai sebuah sistem lengkap untuk memastikan apakah sesuai dengan kebutuhan perangkat lunak atau tidak.

5. Penerapan dan pemeliharaan

Tahapan ini merupakan tahapan yang memakan waktu tidak sedikit. Sistem di pasang dan digunakan secara langsung. Pemeliharaan melibatkan pembetulan kesalahan yang tidak ditemukan pada tahapan sebelumnya.

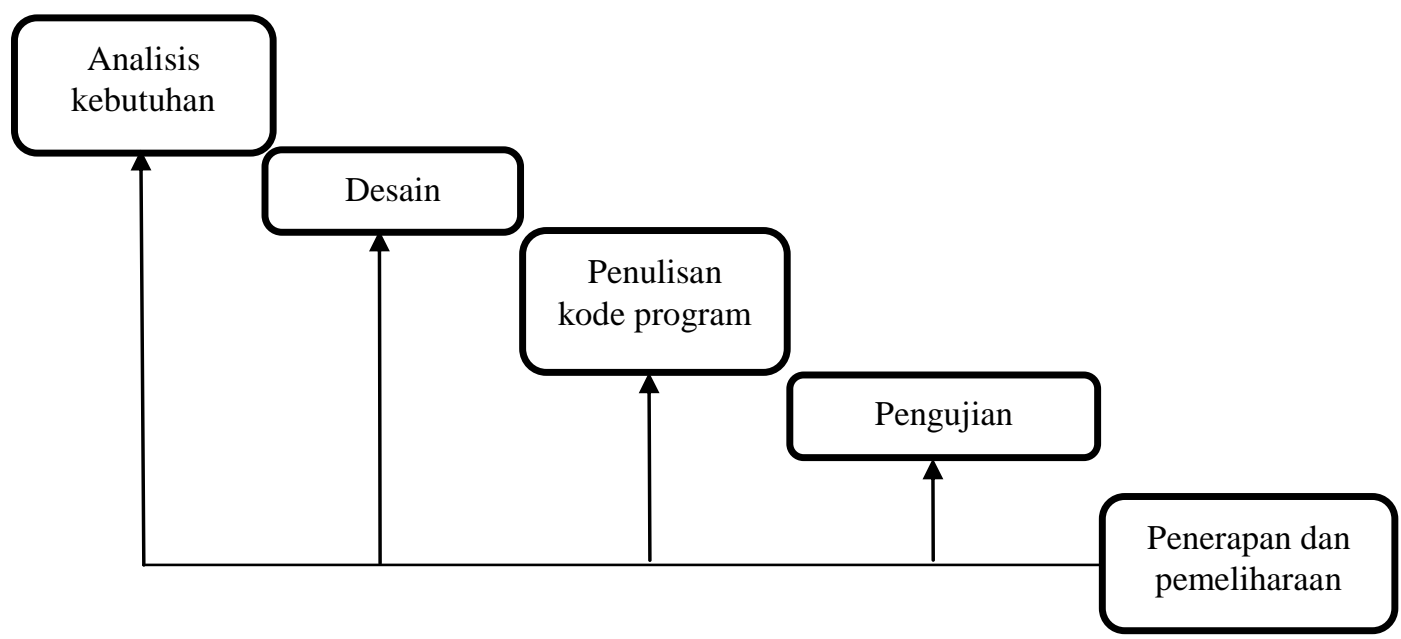

Gambar 1. Ilustrasi Model Waterfall

\section{HASIL DAN PEMBAHASAN}

Bantuan Sosial selama pandemic Covid-19 yang telah direalisasikan oleh pemeritah dalam menanggulangi dampak pandemic telah banyak disalurkan ke masyarakat di seluruh Indonesia di berbagai Desa. Salah satunya adalah Desa Ujung Sedang, Kecamatan Tanjung Morawa, Kabupaten Deli Serdang.

Analisis masalah yang terjadi ialah tidak terdatanya secara benar terhadap masyarakat yang layak menerima bantuan sosial tersebut. Kriteria - krtieria yang dihasilkan dirasa sulit oleh petugas dalam menganalisis masyarakat yang benar-benar layak menerima bantuan sosial. Kesulitan tersebut berupa petugas yang tidak mencukupi dalam menganalisis yang benar terhadap jumlah penduduk yang banyak pada Desa tersebut sehingga proses penyeleksian yang cenderung lama dan tidak akurat. Untuk itu penulis mempunyai ide untuk menganalisis masyarakat yang benar layak mendapatkan bantuan sosial dengan kriteria-kriteria yang sudah di atur oleh pemerintah ${ }^{[5]}$. Diharapkan petugas nantikan akan lebih cepat dan tepat dalam menganalisa setiap masyarakat yang layak menerima bantuan sosial dan memimalisir kecemburuan sosial antar warga

Analisis penerima bantuan sosial covid-19 menggunakan metode ROC (Rank Order Centroid) merupakan metode baru yang dapat di pakai dalam penentuan penerima bantuan sosial covid-19 pada 
Desa Ujung Sedang, Kecamatan Tanjung Morawa, Kabupaten Deli Serdang.

\section{Metode Rank Order Centroid (ROC)}

Dalam penentuan penerima bantuan sosial covid-19 pada Desa Ujung Sedang, Kecamatan Tanjung Morawa, Kabupaten Deli Serdang dengan menggunakan metode ROC diperlukan kriteria dan bobot untuk melakukan perhitungannya sehingga akan mendapatkan masyarakat yang layak untuk menerima bantuan sosial covid-19.

Dalam metode ROC terdapat kriteria yang dibutuhkan untuk Analisis Pengaruh Penerima Bantuan Sosial Covid-19. Adapun nilai bobot pada Kriteria yang telah di tentukan oleh pembuat keputusan pada salah satu aparatur pemerintah pada Desa Ujung Sedang, Kecamatan Tanjung Morawa, Kabupaten Deli Serdang dapat dilihat pada tabel 1. berikut ini :

Tabel 1. Tabel Kriteria

\begin{tabular}{|l|c|}
\hline \multicolumn{1}{|c|}{ KRITERIA } & SKALA PRIORITAS \\
\hline Keterangan Domisili & Prioritas Utama \\
Pendapatan & Prioritas Kedua \\
Pekerjaan & Prioritas Ketiga \\
Status Tempat Tinggal & Prioritas Keempat \\
Jumlah Anak & Prioritas Kelima \\
Kendaraan Bermotor & Prioritas Keenam \\
Status Perkawinan & Prioritas Ketujuh \\
\hline
\end{tabular}

Dari Tabel 1. sudah diketahui kriteria - kriteria serta skala prioritas. Prioritas pertama ditempatkan pada kriteria Keterangan Domisili dikarenakan diprioritaskan adalah penduduk setempat yang beralamatkan pada KTP, bukan surat keterangan tempat tinggal sementara. Disusul dengan kriteria Pendapatan, Pekerjaan dan sebagainya. Maka selanjutnya mencari nilai bobot dengan prosedur metode $R O C$ sebagai berikut.

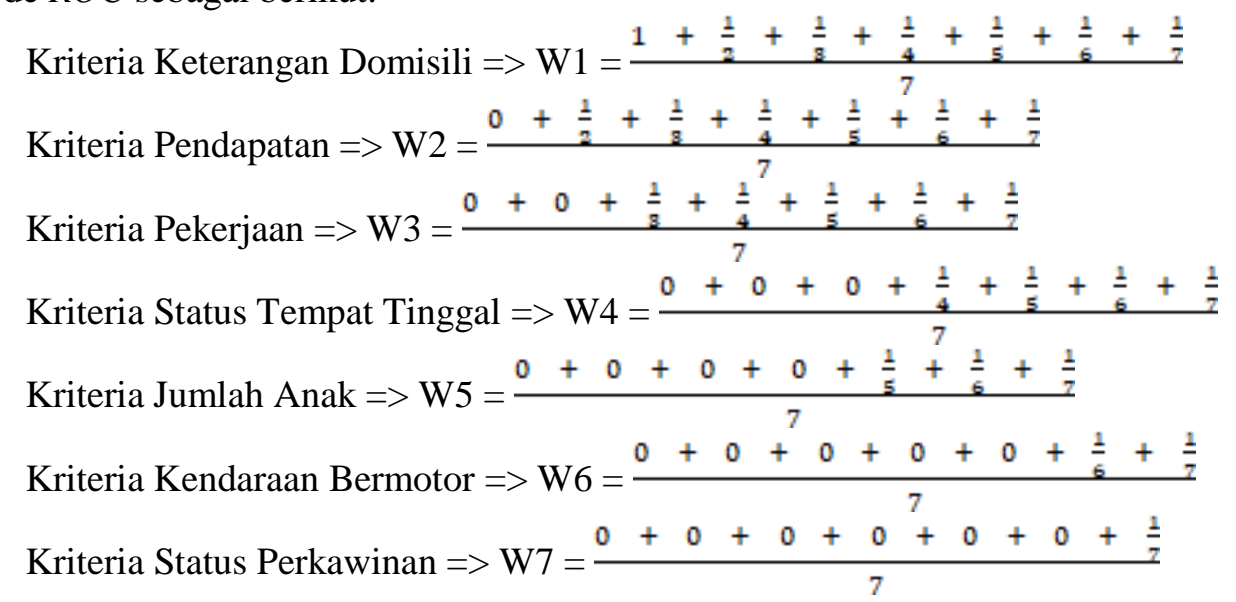

Sehingga hasil perhitungan ROC terhadap pencarian bobot Kriteria dapat di lihat pada tabel 2.

Tabel 2. Hasil Perhitungan ROC Terhadap Kriteria

\begin{tabular}{|l|c|}
\hline \multicolumn{1}{|c|}{ KRITERIA } & Hasil ROC \\
\hline Keterangan Domisili & 0.370 \\
Pendapatan & 0.228 \\
Pekerjaan & 0.156 \\
Status Tempat Tinggal & 0.109 \\
Jumlah Anak & 0.073 \\
Kendaraan Bermotor & 0.044 \\
\hline
\end{tabular}




\begin{tabular}{|l|c|}
\hline Status Perkawinan & 0.020 \\
\hline
\end{tabular}

Setelah mengetahui nilai bobot pada kriteria dengan perhitungan ROC, maka selanjutnya mencari nilai bobot subkriteria dengan metode ROC juga.

1. Subkriteria Dari Kriteria Keterangan Domisili

Subkriteria pada kriteria Keterangan Domisili memiliki 3(tiga) anggota yaitu KTP Domisili Setempat, Surat Tinggal Sementara dan Tidak Mempunyai Keterangan. Maka perhitungan metode ROC sebagai berikut.

$$
\begin{aligned}
& \text { Subkriteria KTP Domisili Setempat }=>\mathrm{W} 1=\frac{1+\frac{1}{3}+\frac{1}{3}}{3} \\
& \text { Subkriteria Surat Tinggal Sementara }=>\mathrm{W} 2=\frac{0+\frac{1}{3}+\frac{1}{3}}{3} \\
& \text { Subkriteria Tidak Mempunyai Keterangan }=>\mathrm{W} 3=\frac{0+0+\frac{1}{3}}{3}
\end{aligned}
$$

Tabel 3 Hasil ROC Subkriteria Dari Kriteria Keterangan Domisili

\begin{tabular}{|c|c|}
\hline Keanggotaan & Hasil ROC \\
\hline KTP Domisili Setempat & 0.611 \\
Surat Tinggal Sementara & 0.278 \\
Tidak Mempunyai Keterangan & 0.111 \\
\hline
\end{tabular}

2. Subkriteria Dari Kriteria Pendapatan

Subkriteria pada kriteria Pendapatan memiliki 3 anggota yaitu $<1.500 .000,1.500 .000-$ 2.500.000, serta $>2.500 .000$. Perhitungan metode ROC sebagai berikut.

Subkriteria $<1.500 .000=>\mathrm{W} 1=\frac{1+\frac{1}{3}+\frac{1}{3}}{3}$

Subkriteria $1.500 .000-2.500 .000=>\mathrm{W} 2=\frac{0+\frac{1}{3}+\frac{1}{3}}{3}$

Subkriteria $>2.500 .000=>\mathrm{W} 3=\frac{0+0+\frac{1}{3}}{3}$

Tabel 4. Hasil ROC Subkriteria Dari Kriteria Pendapatan

\begin{tabular}{|c|c|}
\hline Keanggotaan & Hasil ROC \\
\hline$<1.500 .000$ & 0.611 \\
$1.500 .000-2.500 .000$ & 0.278 \\
$>2.500 .000$ & 0.111 \\
\hline
\end{tabular}

3. Subkriteria Dari Kriteria Pekerjaan

Subkriteria pada kriteria Pekerjaan memiliki 5 keanggotaan yaitu Tidak Mempunyai Pekerjaan, Pemulung, Buruh Harian, Buruh Pabrik dan Pegawai Pemerintah. Maka perhitungan metode ROC sebagai berikut.

$$
\begin{aligned}
& \text { Subkriteria Tidak Mempunyai Pekerjaan }=>\mathrm{W} 1=\frac{1+\frac{1}{3}+\frac{1}{3}+\frac{1}{4}+\frac{1}{5}}{5} \\
& \text { Subkriteria Pemulung }=>\mathrm{W} 2=\frac{0+\frac{1}{3}+\frac{1}{8}+\frac{1}{4}+\frac{1}{5}}{5} \\
& \text { Subkriteria Buruh Harian }=>\mathrm{W} 3=\frac{0+0+\frac{1}{8}+\frac{1}{4}+\frac{1}{5}}{5} \\
& \text { Subkriteria Buruh Pabrik }=>\mathrm{W} 4=\frac{0+0+0+\frac{1}{4}+\frac{1}{5}}{5} \\
& \text { Subkriteria Pegawai Pemerintah }=>\mathrm{W} 5=\frac{0+0+0+0+\frac{1}{5}}{5}
\end{aligned}
$$


Tabel 5. Hasil ROC Subkriteria Dari Kemudahan Pekerjaan

\begin{tabular}{|c|c|}
\hline Keanggotaan & Hasil ROC \\
\hline Tidak Punya Pekerjaan & 0.456 \\
Pemulung & 0.256 \\
Buruh Harian & 0.157 \\
Buruh Pabrik & 0.09 \\
Pegawai Pemerintah & 0.04 \\
\hline
\end{tabular}

4. Subkriteria Dari Kriteria Status Tempat Tinggal

Ketepatan Metode merupakan kriteria Status Tempat Tinggal mempunyai 5 keanggotaan juga seperti halnya Pekerjaan. Perhitungan metode ROC sebagai berikut.

Subkriteria Menumpang Dengan Orang Lain $=>\mathrm{W} 1=\frac{1+\frac{1}{3}+\frac{1}{8}+\frac{1}{4}+\frac{1}{5}}{5}$

Subkriteria Kos $=>\mathrm{W} 2=\frac{0+\frac{1}{3}+\frac{1}{3}+\frac{1}{4}+\frac{1}{5}}{5}$

Subkriteria Menyewa Rumah $=>\mathrm{W} 3=\frac{0+0+\frac{1}{3}+\frac{1}{4}+\frac{1}{5}}{5}$

Subkriteria Tinggal Dengan Orang Tua $=>\mathrm{W} 4=\frac{0+0+0+\frac{1}{4}+\frac{1}{5}}{5}$

Subkriteria Rumah Milik Pribadi $=>$ W5 $=\frac{0+0+0+0+\frac{1}{5}}{5}$

Tabel 6. Hasil ROC Subkriteria dari Kriteria Status Tempat Tinggal

\begin{tabular}{|c|c|}
\hline Keanggotaan & Hasil ROC \\
\hline Menumpang Dengan Orang Lain & 0.456 \\
Kos & 0.256 \\
Menyewa Rumah & 0.157 \\
Tidak Dengan Orang Tua & 0.09 \\
Rumah Milik Pribadi & 0.04 \\
\hline
\end{tabular}

5. Subkriteria Dari Kriteria Jumlah Anak

Kriteria Jumlah Anak merupakan kriteria yang mengetahui ada berapa jumlah anak pada keluarga. Keanggotaan subkriteria pada kriteria Jumlah Anak memiliki 5 unsur.

Subkriteria $>4$ anak $=>\mathrm{W} 1=\frac{1+\frac{1}{3}+\frac{1}{3}+\frac{1}{4}+\frac{1}{5}}{5}$

Subkriteria 4 anak $=>\mathrm{W} 2=\frac{0+\frac{1}{3}+\frac{1}{3}+\frac{1}{4}+\frac{1}{5}}{5}$

Subkriteria 3 Anak $=>\mathrm{W} 3=\frac{0+0+\frac{1}{8}+\frac{1}{4}+\frac{1}{5}}{5}$

Subkriteria $1-2$ Anak $=>\mathrm{W} 4=\frac{0+0+0+\frac{1}{4}+\frac{1}{5}}{5}$

Subkriteria Tidak Ada Anak $=>$ W5 $=\frac{0+0+0+0+\frac{1}{5}}{5}$

Tabel 7. Hasil ROC Subkriteria dari Kriteria Jumlah Anak

\begin{tabular}{|c|c|}
\hline Keanggotaan & Hasil ROC \\
\hline$>$ 4 Anak & 0.456 \\
4 Anak & 0.256 \\
3 Anak & 0.157 \\
1 - 2 Anak & 0.09 \\
Tidak Ada Anak & 0.04 \\
\hline
\end{tabular}


6. Subkriteria Dari Kriteria Kendaraan Bermotor

Kriteria Kendaraan Motor mempunyai 3 keanggotaan subkriteria yaitu Tidak Punya Tidak hanya ada 1 motor dibawah $100 \mathrm{CC}$ serta Ada Banyak Kendaraan Bermotor. Perhitungan ROC sebagai berikut.

Subkriteria Tidak Punya $=>\mathrm{W} 1=\frac{1+\frac{1}{3}+\frac{1}{3}}{3}$

Subkriteria Ada 1 Motor dibawah $100 \mathrm{CC}=>\mathrm{W} 2=\frac{0+\frac{1}{3}+\frac{1}{3}}{3}$

Subkriteria Ada Banyak Kendaraan Bermotor $=>$ W $3=\frac{0+0+\frac{1}{3}}{3}$

Tabel 8. Subkriteria dari Kendaraan Bermotor

\begin{tabular}{|c|c|}
\hline Keanggotaan & Nilai (Bobot) \\
\hline Tidak Punya & 0.611 \\
Ada 1 Motor dibawah 100 CC & 0.278 \\
Ada Banyak Kendaraan Bermotor & 0.111 \\
\hline
\end{tabular}

7. Subkriteria Dari Kriteria Status Perkawinan

Kriteria Status Perkawinan mempunyai keanggotaan subkriteria terdapat 3 unsur. Perhitungan Metode ROC sebagai berikut.

Subkriteria Duda $/$ Janda $=>\mathrm{W} 1=\frac{1+\frac{1}{3}+\frac{1}{3}}{3}$

Subkriteria Menikah $=>\mathrm{W} 2=\frac{0+\frac{1}{3}+\frac{1}{3}}{3}$

Subkriteria Single $=>\mathrm{W} 3=\frac{0+0+\frac{1}{3}}{3}$

Tabel 9. Hasil ROC Subkriteria dari Kriteria Kepala

\begin{tabular}{|c|c|}
\hline Keanggotaan & Hasil ROC \\
\hline Duda / Janda & 0.611 \\
Menikah & 0.278 \\
Single & 0.111 \\
\hline
\end{tabular}

Setelah mengetahui seluruh nilai bobot kriteria dan subkriteria. Selanjutnya mengetahui kasus. Kasus di dapat dari data penelitian yang telah dilakukan oleh penulis. Data penelitian terdapat 5 warga sebagai sampling dan juga sebagai alternatif yang akan di bandingkan antar warga tersebut berdasarkan nilai kriterianya masing-masing.

Tabel 10 Data Kasus

\begin{tabular}{|c|c|c|c|c|c|c|c|c|}
\hline \multirow{3}{*}{\multicolumn{2}{|c|}{ Alternatif }} & \multicolumn{7}{|c|}{ Kriteria } \\
\hline & & \multirow{2}{*}{$\begin{array}{l}\begin{array}{l}\text { Ket. } \\
\text { Domsli }\end{array} \\
\text { C1 } \\
\end{array}$} & \multirow{2}{*}{$\frac{\text { Pendapatan }}{\mathrm{C} 2}$} & \multirow{2}{*}{$\begin{array}{c}\text { Pekerjaan } \\
\text { C3 }\end{array}$} & \multirow{2}{*}{$\begin{array}{c}\text { Sts Tpt } \\
\text { Tinggal } \\
\mathrm{C} 4\end{array}$} & \multirow{2}{*}{$\begin{array}{l}\text { Jlh } \\
\text { Anak } \\
\text { C5 }\end{array}$} & \multirow{2}{*}{$\begin{array}{r}\begin{array}{l}\text { Kendaraan } \\
\text { Bermotor }\end{array} \\
\text { C6 } \\
\end{array}$} & \multirow{2}{*}{$\begin{array}{l}\begin{array}{l}\text { Sts } \\
\text { Perkawinan } \\
\text { C7 }\end{array} \\
\end{array}$} \\
\hline & & & & & & & & \\
\hline 1 & $\begin{array}{l}\text { Warga } \\
\text { A }\end{array}$ & $\begin{array}{l}\text { Surat } \\
\text { Tinggal } \\
\text { Sementra }\end{array}$ & $>2.500 .000$ & Pemulung & $\begin{array}{l}\text { Numpang } \\
\text { Dengan } \\
\text { Orang } \\
\text { Lain }\end{array}$ & $\begin{array}{l}6 \\
\text { Anak }\end{array}$ & $\begin{array}{l}\text { Ada } 1 \text { Motor } \\
\text { dibawah } 100 \mathrm{CC} \\
\text { Ada }\end{array}$ & Menikah \\
\hline 2 & $\begin{array}{l}\text { Warga } \\
\text { B }\end{array}$ & $\begin{array}{l}\text { KTP } \\
\text { Domisili } \\
\text { Setempat }\end{array}$ & $\begin{array}{l}1.500 .000- \\
2.500 .000\end{array}$ & Pemulung & $\begin{array}{l}\text { Numpang } \\
\text { Dengan } \\
\text { Orang }\end{array}$ & $\begin{array}{l}7 \\
\text { Anak }\end{array}$ & $\begin{array}{l}\text { Ada } 1 \text { Motor } \\
\text { dibawah } 100 \mathrm{CC} \\
\text { Ada }\end{array}$ & Menikah \\
\hline
\end{tabular}




\begin{tabular}{|c|l|l|l|l|l|l|l|l|}
\hline & & & & Lain & & \\
\hline 3 & $\begin{array}{l}\text { Warga } \\
\text { C }\end{array}$ & $\begin{array}{l}\text { KTP } \\
\text { Domisili } \\
\text { Setempat }\end{array}$ & $>2.500 .000$ & Pemulung & $\begin{array}{l}\text { Numpang } \\
\text { Dengan } \\
\text { Orang } \\
\text { Lain }\end{array}$ & $\begin{array}{l}\text { 6 } \\
\text { Anak }\end{array}$ & $\begin{array}{l}\text { Ada 1 Motor } \\
\text { dibawah 100 CC } \\
\text { Ada }\end{array}$ & Menikah \\
\hline 4 & $\begin{array}{l}\text { Warga } \\
\text { D }\end{array}$ & $\begin{array}{l}\text { Tidak ada } \\
\text { Surat }\end{array}$ & $<1.500 .000$ & Pemulung & $\begin{array}{l}\text { Numpang } \\
\text { Dengan } \\
\text { Orang } \\
\text { Lain }\end{array}$ & $\begin{array}{l}5 \\
\text { Anak }\end{array}$ & Tidak Punya & Menikah \\
\hline 5 & $\begin{array}{l}\text { Warga } \\
\text { E }\end{array}$ & $\begin{array}{l}\text { KTP } \\
\text { Domisili } \\
\text { Setempat }\end{array}$ & $\begin{array}{l}1.500 .000- \\
2.500 .000\end{array}$ & Pemulung & $\begin{array}{l}\text { Numpang } \\
\text { Dengan } \\
\text { Orang } \\
\text { Lain }\end{array}$ & $\begin{array}{l}5 \\
\text { Anak }\end{array}$ & $\begin{array}{l}\text { Ada Banyak } \\
\text { Kendaraan }\end{array}$ & Menikah \\
\hline
\end{tabular}

Dari data kasus tabel 10 maka selanjutnya di transformasi dalam bentuk nilai bobot subkriteria yang telah di cari / dihitung sebelumnya.

Tabel 11. Data Transformasi Nilai

\begin{tabular}{|c|c|c|c|c|c|c|c|c|}
\hline \multirow{2}{*}{\multicolumn{2}{|c|}{ Alternatif }} & \multicolumn{7}{|c|}{ Kriteria } \\
\hline & & $\begin{array}{l}\begin{array}{l}\text { Ket. } \\
\text { Domsli }\end{array} \\
\mathrm{C} 1\end{array}$ & $\frac{\text { Pendapatan }}{\mathrm{C} 2}$ & $\frac{\text { Pekerjaan }}{\text { C3 }}$ & $\begin{array}{l}\text { Sts Tpt } \\
\text { Tinggal } \\
\text { C4 }\end{array}$ & $\begin{array}{l}\text { Jlh } \\
\text { Anak } \\
\text { C5 }\end{array}$ & $\begin{array}{c}\text { Kendaraan } \\
\text { Bermotor } \\
\text { C6 }\end{array}$ & $\begin{array}{c}\text { Sts Perkawinan } \\
\text { C7 }\end{array}$ \\
\hline A1 & $\begin{array}{c}\text { Warga } \\
\text { A }\end{array}$ & 0.278 & 0.111 & 0.256 & 0.456 & 0.456 & 0.278 & 0.278 \\
\hline $\mathrm{A} 2$ & $\begin{array}{c}\text { Warga } \\
\text { B }\end{array}$ & 0.611 & 0.278 & 0.256 & 0.456 & 0.456 & 0.278 & 0.278 \\
\hline A3 & $\begin{array}{c}\text { Warga } \\
\text { C }\end{array}$ & 0.611 & 0.111 & 0.256 & 0.456 & 0.456 & 0.278 & 0.278 \\
\hline A4 & $\begin{array}{c}\text { Warga } \\
\text { D }\end{array}$ & 0.111 & 0.611 & 0.256 & 0.456 & 0.456 & 0.611 & 0.278 \\
\hline A5 & $\begin{array}{c}\text { Warga } \\
\mathrm{E}\end{array}$ & 0.611 & 0.278 & 0.256 & 0.456 & 0.456 & 0.111 & 0.278 \\
\hline
\end{tabular}

Selanjutnya menghitung nilai keputusannya. Nilai keputusan juga memakai prosedur metode rank order centroid (ROC) sehingga akan diketahui mana warga yang tepat untuk layak mendapatkan bantuan sosial covid-19.

$$
\begin{aligned}
\mathrm{A} 1 & =(0.278 \times 0.370)+(0.111 \times 0.228)+(0.256 \times 0.156)+(0.456 \times 0.109) \\
+ & (0.456 \times 0.073)+(0.278 \times 0.044)+(0.278 \times 0.020) \\
& =0.269 \\
\mathrm{~A} 2 & =(0.611 \times 0.370)+(0.278 \times 0.228)+(0.256 \times 0.156)+(0.456 \times 0.109) \\
+ & (0.456 \times 0.073)+(0.278 \times 0.044)+(0.278 \times 0.020) \\
\quad & =0.43 \\
\mathrm{~A} 3 & =(0.611 \times 0.370)+(0.111 \times 0.228)+(0.256 \times 0.156)+(0.456 \times 0.109) \\
+ & (0.456 \times 0.073)+(0.278 \times 0.044)+(0.278 \times 0.020) \\
\quad & =0.362 \\
\mathrm{~A} 4 & =(0.111 \times 0.370)+(0.611 \times 0.228)+(0.256 \times 0.156)+(0.456 \times 0.109) \\
+ & (0.456 \times 0.073)+(0.611 \times 0.044)+(0.278 \times 0.020) \\
& =0.336 \\
\mathrm{~A} 5 & =(0.611 \times 0.370)+(0.278 \times 0.228)+(0.256 \times 0.156)+(0.456 \times 0.109)
\end{aligned}
$$


$+(0.456 \times 0.073)+(0.111 \times 0.044)+(0.278 \times 0.020)$

$=0.423$

Maka hasilnya jika di urutkan

Tabel 12. Hasil

\begin{tabular}{|r|c|c|}
\hline \multicolumn{1}{|l|}{ NO } & Alternatif & Hasil \\
\hline 1 & Warga B & 0.43 \\
\hline 2 & Warga E & 0.423 \\
\hline 3 & Warga C & 0.362 \\
\hline 4 & Warga D & 0.336 \\
\hline 5 & Warga A & 0.269 \\
\hline
\end{tabular}

Kesimpulan : Dari hasil di dapat Warga B memiliki nilai 0.43 yang tertinggi. Sehingga Warga B merupakan calon penerima bantuan sosial covid-19 paling di kategorikan layak. Selanjutnya diduduki oleh warga E dengan nilai 0.423 merupakan calon penerima bantuan sosial covid-19. Disusul Warga C, Warga D dan Warga A.

\section{KESIMPULAN}

Dari hasil pengujian terhadap sub sistem secara dapatlah dibuat suatu kesimpulan sebagai berikut:

1. Penerima bantuan sosial covid-19 pada Desa Ujung Sedang, Kecamatan Tanjung Morawa, Kabupaten Deli Serdang memerlukan analisis pengelolaan data agar penentuan penerima bantuan sosial dapat direalisasikan dengan cepat dan tepat.

2. Metode rank order centroid (ROC) merupakan metode terbaru dari semesta Sistem Pendukung Keputusan yang dapat menjawab kesulitan dalam pengelolaan kriteria penerima bantuan sosial Covid-19 Desa Ujung Sedang, Kecamatan Tanjung Morawa, Kabupaten Deli Serdang sehingga tercapai pengidentifikasian dengan tepat.

3. Warga B memiliki nilai tertinggi sehingga menjadi kandidat paling utama mendapatkan bantuan sosial Covid-19.

\section{SARAN}

Adapun saran yang dapat penulis kemukakan adalah sebagai berikut :

1. Diharapkan adanya pemeriksaan lanjutan mengenai penambahan kriteria pada penerima bantuan sosial selain dari penelitian ini.

2. Diperlukan sebuah perancangan sistem yang lebih akurat sehingga penelitian ini dapat dikembangkan lagi dan menjadi lebih baik.

3. Peningkatan jumlah data yang dibandingkan sehingga akan banyak software sistem pendukung keputusan akan menghasilkan analisa yang lebih baik. 


\section{DAFTAR PUSTAKA}

[1]. Astiani, N., Andreswari, D., \& Setiawan, Y. (2016). Aplikasi Sistem Pendukung Keputusan Tanaman Obat Herbal Untuk Berbagai Penyakit Dengan Metode Roc (Rank Order Centroid) Dan Metode Oreste Berbasis Mobile Web. J. Teknol. Komput. dan Inform, 12(2), 125-140.

[2]. Badaruddin, M. (2019). Sistem Pendukung Keputusan Penilaian Kinerja Karyawan Menerapkan Kombinasi Metode Simple Additive Weighting (SAW) dengan Rank Order Centroid (ROC). Jurnal Media Informatika Budidarma, 3(4), 366-370.

[3]. Handayani, L., Syahrizal, M., \& Tampubolon, K. (2019). Pemilihan Kepling Teladan Menerapkan Metode Rank Order Centroid (Roc) Dan Metode Additive Ratio Assessment (Aras) Di Kecamatan Medan Area. KOMIK (Konferensi Nasional Teknologi Informasi dan Komputer), 3(1).

[4]. Mesran, M., Afriany, J., \& Sahir, S. H. (2019, September). Efektifitas Penilaian Kinerja Karyawan Dalam Peningkatan Motivasi Kerja Menerapkan Metode Rank Order Centroid (ROC) dan Additive Ratio Assessment (ARAS). In Prosiding Seminar Nasional Riset Information Science (SENARIS) (Vol. 1, pp. 813-821).

[5]. Ndruru, R. K. (2020, February). Penerapan Metode Additive Ratio Assessment (ARAS) dan Rank Order Centroid (ROC) Dalam Pemilihan Jaksa Terbaik Pada Kejaksaan Negeri Medan. In Seminar Nasional Teknologi Komputer \& Sains (SAINTEKS) (Vol. 1, No. 1, pp. 367-372).

[6]. Saputra, M. (2020). SISTEM PENDUKUNG KEPUTUSAN PEMILIHAN AIR MINUM ISI ULANG TERBAIK DAERAH MEDAN MARELAN. Jurnal Teknovasi: Jurnal Teknik dan Inovasi, 7(3), 6-12.

[7]. Saputra, M., Sitompul, O. S., \& Sihombing, P. (2018, April). Comparison AHP and SAW to promotion of head major department SMK Muhammadiyah 04 Medan. In Journal of Physics: Conference Series (Vol. 1007, No. 1, p. 012034). IOP Publishing.

[8]. Saputra, M., Aisyah, S., Novelan, M. S., \& Lius, J. (2020). Implementation of Profile Matching Method to Determine the Performance Evaluation of the Best Information Systems Lecturer at Prima Indonesia University: Implementation of Profile Matching Method to Determine the Performance Evaluation of the Best Information Systems Lecturer at Prima Indonesia University. Jurnal Mantik, 4(1), 283-288. Retrieved from http://iocscience.org/ejournal/index.php/mantik/article/view/742

[9]. Silvilestari, S. (2019). Penerapan Kombinasi Metode Simple Additive Weighting (SAW) dan Rank Order Centroid (ROC) dalam Keputusan Pemberian Kredit. JURNAL MEDIA INFORMATIKA BUDIDARMA, 3(4), 371-375.

[10]. Utami, R. T., Andreswari, D., \& Setiawan, Y. (2016). Implementasi Metode Simple Additive Weighting (SAW) Dengan Pembobotan Rank Order Centroid (ROC) Dalam Pengambilan Keputusan Untuk Seleksi Pengguna Jasa Leasing Mobil. Rekursif: Jurnal Informatika, 4(2). 